\title{
Application of tripolite in the production of facing ceramic material using Cullet
}

\author{
A.S. Uvarova ${ }^{1}$, I.A. Vitkalova ${ }^{2}$, E.S. Pikalov ${ }^{3}$, O.G. Selivanov ${ }^{4}$ \\ ${ }^{1}$ Vladimir State University named after A. G. and N. G. Stoletovs, Vladimir, Russian Federation \\ astorlova@mail.ru \\ ${ }^{2}$ Vladimir State University named after A. G. and N. G. Stoletovs, Vladimir, Russian Federation, \\ iavitkalova@gmail.com \\ ${ }^{3}$ Vladimir State University named after A. G. and N. G. Stoletovs, Vladimir, Russian Federation \\ evgeniy-pikalov@mail.ru \\ ${ }^{4}$ Vladimir State University named after A. G. and N. G. Stoletovs, Vladimir, Russian \\ Federation,selivanov6003@mail.ru
}

\begin{abstract}
The paper presents the results of the charge composition development including low-plasticity clay as the main component, boric acid as the flux, cullet as the fluxingstrengthening additive and tripolite as the component forming a fine-pored ceramics structure. The research results include the dependence of facade ceramics bending strength and thermal conductivity on the charge components ratio, confirming the role of each additive and allowing to determine their ratio ensuring the ceramics quality. The paper also contains information describing main physical and mechanical properties of the developed material, which prove that the resulting ceramics is energy-efficient, allows obtaining products, characterized by the reduced weight and meeting the regulatory requirements for external tiles for the walls and plinths.
\end{abstract}

Key words: Facing ceramics, self-glazing, low-plasticity clay, energy efficiency, cullet, tripolite

\section{INTRODUCTION}

Facing facades and plinths of the buildings with the ceramic products is widely and successfully used in both small and high-rise construction. In comparison with the other facade cladding materials, ceramics is characterized by preserving its properties at a wide range of temperatures, low water absorption, high frost resistance and mechanical strength, including the ability to resist to almost any wind load which increases with the building height. It is also worth considering that ceramics is one of the best options in terms of facade aesthetics $[1,2]$.

Like any other material, ceramics has certain disadvantages, which include relatively large mass, creating the load on the walls and foundation, high products cost, fragility, brittleness and low vapor permeability, which prevents the moisture vaporization from the walls, worsening thermal insulation and service life of the construction [2-4].

Brittleness and fragility require careful mounting of the products. To eliminate the problem of low vapor permeability, it is necessary to mount facade ceramics on the crate according to the ventilated facades system instructions.
An additional advantage of facade ceramics, helping to minimize its disadvantages and increase products performance properties is wide possibilities for its modification by introducing various functional additives [5-7].

The research authors have previously conducted a number of studies devoted to the development of facing ceramic products, which cost was reduced due to the application of low-quality clay raw materials and introduction of the low-cost components into the charge, including anthropogenic waste. The principle advantages of the produced materials were liquid-phase sintering due to the application of fusible components and fluxes, which allowed strength and frost resistance increase, as well as obtaining self-glazing effect of the products surface, thus improving the products appearance, reducing cracking and water absorption [2, 8, 9]. During the experimental development the product mass decrease was achieved by increasing its porosity causing energy efficiency improvement $[9,10]$.

In one of our previous researches, tripolite was used to ensure energy efficiency of facing ceramics with the effect of self-glazing and liquid-phase sintering [11]. The research objective was to determine the amount of tripolite relative to other charge components for producing facade ceramics possessing good performance properties and reduced density and thermal conductivity.

\section{RESEARCH OBJECTS AND METHODS}

The main component of the studied charge composition was clay Suvorotskoe deposits of the Vladimir region. Its plasticity index, identified by the standard method, ranks 5.2, which indicates low plasticity clay and consequently poor strength and highwater absorption of the products. Therefore, it is necessary to introduce special additives to improve the products quality. The used clay was of the following composition (in wt.\%): $\mathrm{SiO}_{2}=67.5 ; \mathrm{Al}_{2} \mathrm{O}_{3}=$ $10.75 ; \mathrm{Fe}_{2} \mathrm{O}_{3}=5.85 ; \mathrm{CaO}=2.8 ; \mathrm{MgO}=1.7 ; \mathrm{K}_{2} \mathrm{O}=2.4$; $\mathrm{Na}_{2} \mathrm{O}=0.7[8,12]$.

Tripolite from Peksha Deposit of the Vladimir region, containing in its composition (in wt. \%): $\mathrm{SiO}_{2}=$ 74.2, $\mathrm{Fe}_{2} \mathrm{O}_{3}=6.9 ; \mathrm{Al}_{2} \mathrm{O}_{3}=9.4 ; \mathrm{CaO}=2.2 ; \mathrm{MgO}=1.6$ was used as a pore-forming additive. The choice of tripolite is explained by the possibility to increase porosity while maintaining sufficiently high strength indicators [11]. 
Window glass cullet serving as an additive for increasing the products strength due to the liquid-phase sintering was received after waste glass grinding of the following composition (in wt.\%): $\mathrm{SiO}_{2}=73.5 ; \mathrm{CaO}=7.4$; $\mathrm{MgO}=1.9 ; \mathrm{Na}_{2} \mathrm{O}=11.1 ; \mathrm{K}_{2} \mathrm{O}=5.2 ; \mathrm{Al}_{2} \mathrm{O}_{3}=0.9[9,11]$.

Boric acid $\mathrm{B}$ 2nd grade in compliance with GOST 18704-78, containing at least 98.6 wt.\% of the main substance was introduced into the charge as a flux. Boric acid reduces the temperature of liquid-phase sintering and jointly with the cullet provides the products self-glazing and glazing effect $[2,8]$.

Before being used as the charge components, clay, tripolite and cullet were separately crushed to make no more than $0.63 \mathrm{~mm}$ particle size and dried to a constant mass. Then all the charge components were mixed in a dry state, afterwards moistened up to $8 \mathrm{wt} \%$. The studied ceramics samples were made from the molding mass at the specific pressing pressure and maximum firing temperature of $1050{ }^{\circ} \mathrm{C}$.

Compressive strength $\left(\sigma_{\mathrm{cmp}}, \mathrm{MPa}\right)$ and bending strength $\left(\sigma_{\text {bnd }}, \mathrm{MPa}\right)$, water absorption (WA, \%), frost resistance (FR, cycles), open $\left(\mathrm{P}_{\mathrm{opn}}, \%\right)$ and total $\left(\mathrm{P}_{\mathrm{t}}, \%\right)$ porosity, density $\left(\mathrm{D}, \mathrm{kg} / \mathrm{m}^{3}\right)$ and thermal conductivity $(\lambda$, $\mathrm{W} / \mathrm{m}^{\circ} \mathrm{C}$ ) have been determined for the produced samples using standard methods for construction ceramic materials.

\section{RESEARCH RESULTS AND DISCUSSION}

Previous experiments revealed that to ensure maximum strength and minimum water absorption for this charge composition, it is necessary to introduce boric acid in the amount of 5 wt. \% [11]. The first stage of this research was devoted to the study of the dependences for the main performance indicators on the ratio of the tripolite amount and cullet $(\mathrm{C})$ in the charge composition.

The research results show that bending strength of the developed ceramics is increasing alongside the cullet amount increase and is decreasing if tripolite amount increases (Fig. 1).

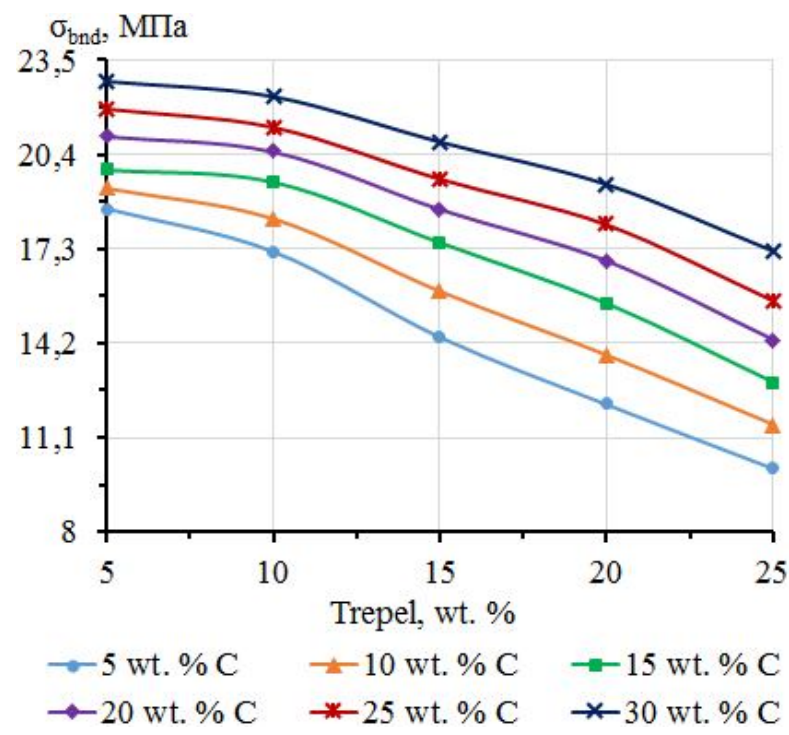

Figure 1:Bending strength dependence on tripolite and cullet amount in the charge composition
The nature of the resulting dependencies is explained by the influence of the studied additives on material porosity, which increase is known to cause the decrease in the material strength.

The cullet component effect on the charge includes its melting during firing and forming a melt that fills the pores in the material depth thus forming the layers of the glass phase between ceramic particles, and forming a rigid frame in the ceramics depth. The boric acid action increases the cullet effect by increasing the melt amount, reducing its formation temperature and being included into its composition.

Tripolite, in its turn, is a pore-forming additive, based on opal microparticles $\mathrm{SiO}_{2} \mathrm{nH}_{2} \mathrm{O}$. During firing at temperatures of $450-800^{\circ} \mathrm{C}$, chemically bound water is removed from these particles, increasing the material porosity. Alkaline oxides of the applied tripolite composition contribute to liquid-phase sintering of ceramics as well as cullet and boric acid. After the chemically bound water removal and alkaline oxides melting, silicon microparticles, similar to the melt, fill large voids between the ceramic particles, contributing to the formation of the fine-pored structure. Herewith the links are formed between the ceramic particles from the layers of glass phase filled with silicon microparticles [11].

The data shown in figure 2 proves that thermal conductivity is increasing when cullet amount increases and is decreasing when tripolite amount increases.

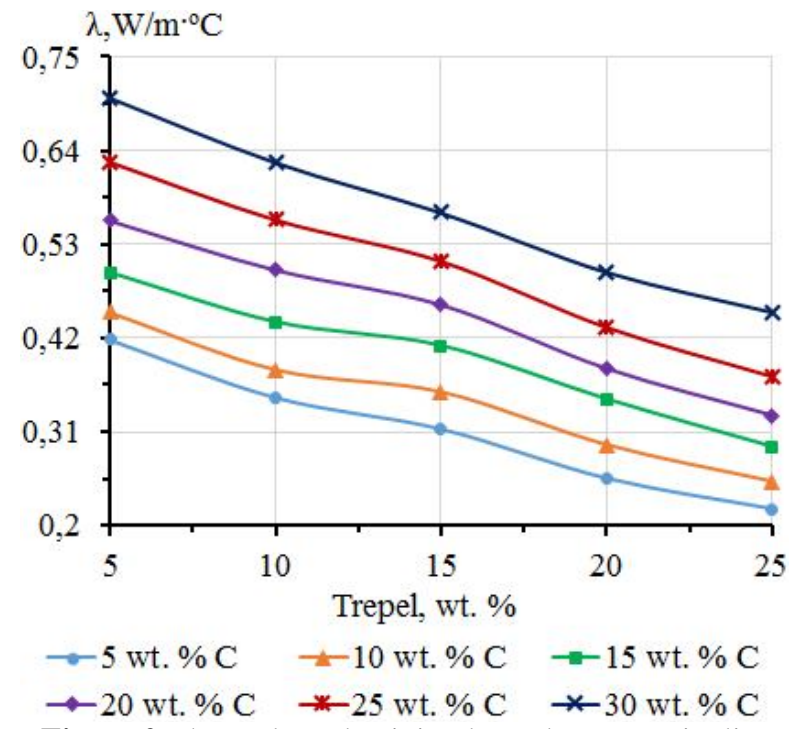

Figure 2: Thermal conductivity dependence on tripolite and cullet amount in the charge composition

Such dependences nature is also explained by the impact of the studied additives on the material porosity which increase, as it is known, causes the thermal conductivity reduction.

As the research objective was to develop energyefficient facade ceramics, in compliance with GOST 13996-93, the material bending strength should be at least $16 \mathrm{MPa}$. Thus we have chosen the charge composition which application allows minimizing thermal conductivity while meeting the requirements for bending strength, i.e. the composition including 3 wt. $\%$ of cullet and 12 wt. $\%$ of tripolite. 
At the second stage the research work, a set of the developed ceramics properties on the basis of the selected charge composition was determined. A comparison of the obtained properties with the regulatory requirements is presented in the table. The research results prove that the developed charge composition allows producing ceramics that meets the regulatory requirements for external tiles for walls and plinths. At the same time, the material thermal conductivity in compliance with GOST 530-2012 allows to classify it as effective in terms of thermal characteristics $\left(\lambda=0.24-0.36 \mathrm{~W} /\left(\mathrm{m}^{\cdot 0} \mathrm{C}\right)\right)$. The ceramics density makes it possible to obtain product mass equal to $16.5 \mathrm{~kg} / \mathrm{m}^{2}$ of 9 $\mathrm{mm}$ thickness, which is less than an average mass of the stoneware slabs equal to $25-35 \mathrm{~kg} / \mathrm{m}^{2}$ of $10-12 \mathrm{~mm}$ thickness, and the average mass of terracotta and clinker tiles equals $35-75 \mathrm{~kg} / \mathrm{m}^{2}$ of $19 \mathrm{~mm}$ thickness. Thus, the resulting ceramic material can be effectively used as facade ceramics.

Table 1: The developed facade ceramics properties

\begin{tabular}{|l|c|c|c|}
\hline \multirow{2}{*}{$\begin{array}{c}\text { Ceramics } \\
\text { property }\end{array}$} & \multicolumn{2}{|c|}{$\begin{array}{c}\text { GOST 13996-93 } \\
\text { requirements for tiles }\end{array}$} & \multirow{2}{*}{$\begin{array}{c}\text { Developed } \\
\text { ceramics }\end{array}$} \\
\cline { 2 - 3 } & wall & plinth & \\
\hline$\rho, \mathrm{kg} / \mathrm{m}^{3}$ & - & - & 1831.6 \\
\hline $\mathrm{P}_{\mathrm{opn}}, \%$ & - & - & 4.4 \\
\hline $\mathrm{P}_{\mathrm{t}}, \%$ & - & - & 21.9 \\
\hline$\Sigma_{\mathrm{com}}, \mathrm{MPa}$ & - & - & 32.4 \\
\hline$\Sigma_{\mathrm{bnd}}, \mathrm{MPa}$ & 16 & 8 & 16.6 \\
\hline $\mathrm{WA}, \%$ & $2-9$ & $2-5$ & 2.3 \\
\hline $\mathrm{FR}, \mathrm{cycles}$ & $>40$ & $>50$ & 53 \\
\hline$\lambda, \mathrm{W} /\left(\mathrm{m}^{\circ} \mathrm{C}\right)$ & $<0.46$ & $<0.46$ & 0.323 \\
\hline
\end{tabular}

\section{CONCLUSIONS}

The research results lead to the charge composition development basing on low-plasticity clay, with the additional introduction of $5 \mathrm{wt}$. $\%$ of boric acid, $3 \mathrm{wt}$. $\%$ of cullet and 12 wt. \% of tripolite. Using tripolite for the facade ceramics production, it should be taken into account that pore-forming effect of the additive exceeds its strengthening effect, so first of all tripolite provides material porosity, and cullet together with boric acid provides liquid-phase sintering, which, in turn, contributes to the strength increase and surface self-glazing effect, transforming most open pores into the closed ones.

The developed charge composition makes it possible to produce energy-efficient facade ceramics characterized by the reduced product weight, thus meeting the regulatory requirements for facade cladding products, reducing heat losses through the tiled surface and reducing the load on the foundation. Additional advantages of the developed composition are the possibility of using lowplasticity clay and cullet, thus expanding the raw material resources for the ceramics production and contributing to the glass waste disposal.

\section{REFERENCES}

1. V. Echarri-Iribarren, F. Echarri-Iribarren, C. Rizo-Maestre "Ceramic panels versus aluminium in buildings: Energy consumption and environmental impact assessment with a new methodology."Applied Energy. 2019, Vol. 233-234, pp. 959-974.
2. V.N. Shakhova, A.V. Berezovskaya, E.S. Pikalov, O.G. Selivanov, É.P. Sysoev "Development of SelfGlazing Ceramic Facing Material Based on LowPlasticity Clay."Glass and Ceramics. 2019, Vol. 76, Iss. 1-2, pp. 11-15.

3. M.J. Carretero-Ayuso, M.P. SáezPérez"Construction flaws in facing brick facades and the risk of associated litigation.'Journal of Building Engineering. 2021, Vol. 33, 101633

4. J.D. Silvestre, J. De Brito"Ceramic tiling in building façades: inspection and pathological characterization using an expert system."Construction and Building Materials. 2011, Vol. 25, Iss. 4, pp. 15601571 .

5. R.M. Novais, M.P. Seabra, J.A. Labrincha "Lightweight dense/porous bi-layered ceramic tiles prepared by double pressing."Journal of Materials Processing Technology. 2015, Vol. 216, pp. 169-177.

6. N.V. Boltakova, G.R. Faseeva, R.R. Kabirov, R.M. Nafikov, Yu.A. Zakharov "Utilization of inorganic industrial wastes in producing construction ceramics. Review of Russian experience for the years 20002015." Waste Management. 2017, Vol. 60, pp. 230-246.

7. R. V. Silva, J. de Brito, C. Q. Lye, R. K. Dhir "The role of glass waste in the production of ceramicbased products and other applications: A review." Journal of Cleaner Production. 2017, Vol. 167, pp. 346364.

8. I.A. Vitkalova, A.S. Uvarova, E.S. Pikalov, O.G. Selivanov "Lanthanum oxide application for modifying the properties of chemically resistant ceramics produced with galvanic sludge additive.'International Journal of Emerging Trends in Engineering Research. 2020, Vol. 8, Iss. 8, pp. 4544-4547.

9. I.A. Vitkalova, A.S. Torlova, E.S. Pikalov, O.G. Selivanov "The use of polymer and glass waste to obtain a self-glazing facing ceramic."Ecology and Industry of Russia. 2019, Vol. 23, Iss. 11, pp. 38-42.

10. K. Perovskaya, D. Petrina, E. Pikalov, O. Selivanov "Polymer waste as a combustible additive for wall ceramics production.' $E 3 S$ Web of Conferences. 2018. Vol. 91, 04007.

11. A.S. Torlova, I.A. Vitkalova, E.S. Pikalov, O.G. Selivanov "Development of facade facing ceramics with self-glazing effect and increased energy efficiency."Advances in Intelligent Systems and Computing. 2020, Vol. 1116, pp. 552-559.

12. O.G. Selivanov, E.S. Pikalov, A.S. Kolosova "Ceramic material for fluoride and phosphate ions removal from natural water.'International Journal of Emerging Trends in Engineering Research. 2020, Vol. 8, Iss. 5, pp. 1732-1735. 